\title{
The counselees' self-reported request for psychological help in genetic counseling for hereditary breast/ovarian cancer: not only psychopathology matters
}

\author{
Joël Vos'*, Christi J. van Asperen', Jan C. Oosterwijk², Fred H. Menko ${ }^{3}$, Margriet J. Collee ${ }^{4}$, Encarna Gomez Garcia ${ }^{5}$ \\ and Aad Tibben ${ }^{6}$ \\ 'Department of Clinical Genetics, Center for Human and Clinical Genetics, Leiden University Medical Center, Leiden, The Netherlands \\ ${ }^{2}$ Department of Clinical Genetics, University Medical Center, Groningen University, Groningen, The Netherlands \\ ${ }^{3}$ Department of Clinical Genetics, VU University Medical Center, Amsterdam, The Netherlands \\ ${ }^{4}$ Department of Clinical Genetics, Erasmus Medical Centre Rotterdam, Rotterdam, The Netherlands \\ ${ }^{5}$ Department of Clinical Genetics, Maastricht University Medical Center, Maastricht, The Netherlands \\ ${ }^{6}$ Department of Clinical Psychology, Vrije Universiteit Amsterdam, Asmterdam, The Netherlands
}

*Correspondence to:

Department of Clinical Genetics,

Center for Human and Clinical

Genetics, Leiden University

Medical Center, Leiden, The

Netherlands. E-mail: A.Tibben@ lumc.nl

\begin{abstract}
Background: Several studies have shown that counselees do not experience psychopathological levels of distress after DNA test result disclosure. However, it has not systematically been studied whether the absence of psychopathology also means that counselees do not want to receive help. Their selfreported request for help may be related not only with psychopathology/distress but also with other psychological needs (e.g., surgery decisions), genetics-specific needs (e.g., feeling vulnerable/ stigmatized), and existential concerns (e.g., meaning in life).

Methods: Questionnaires were filled in by Dutch cancer patients, before and after disclosure of BRCA1/2 test results for hereditary breast/ovarian cancer: pathogenic mutation results $(n=30)$, uninformative results $(n=202)$, or unclassified variants $(n=16)$. Newly developed questions measured request for help, psychopathology was estimated with factor analyses on distress/psychopathology instruments, and several validated questionnaires measured other needs/concerns.

Results: One-third of all counselees who reported a request for psychological help had actually received help. The level of psychopathology correlated between 0.34 and 0.44 with this self-reported need-for-help. Other needs, genetics-specific distress, and existential concerns correlated strongly/moderately with the counselees' self-reported need-for-help. Examples of other needs were intention to undergo surgery, inaccuracy of their interpretation, the impact of cancer, and family communication difficulties. Genetics-specific distress was for instance feeling vulnerable to develop cancer, stigma, and lack of mastery. Existential concerns were, among others, lack of purpose in life, low self-acceptance, and an unfulfilled wish for certainty.

Conclusions: The request for help is related to multiple factors. Referral to psychosocial professionals may be improved by not only discussing psychopathology during genetic-counseling sessions but also by other needs and existential concerns. Questions about other needs and existential issues may be added to psychological screening instruments.

Copyright (C) 2012 John Wiley \& Sons, Ltd.
\end{abstract}

\section{Introduction}

In genetic counseling for hereditary cancer, the genetic counselor usually explores the potential psychological consequences of DNA testing with the counselee and provides emotional support. Some counselees may benefit from referral to a psychologist or social worker, as suggested by national and international guidelines [1,2]. Psychologists may offer psychotherapeutic counseling, and a social worker may help with psychosocial issues (in the Netherlands, a social worker is a professional with a bachelor title, who mainly focuses on psychosocial issues instead of psychotherapy). However, which counselees should be referred to a psychologist or social worker?

Until recently, psychologists and social workers with specific expertise in genetic counseling were frequently and intensively involved in the care of patients who received genetic counseling, for instance as standard procedure in genetic counseling in the Netherlands. It was assumed that genetic counseling may be a psychologically difficult process, which may evoke psychopathological levels of distress in some counselees (e.g., clinically diagnosed depression or anxiety), although the operationalization and the level of distress seemed to be a matter of debate (e.g., [3-8]). Recently, the support of a specialized psychologist or social worker is becoming a non-standard element of genetic counseling, especially regarding oncogenetics. Counselees may request and receive psychological help for a broad range of reasons, but this help is not automatically offered. This transformation in the psychosocial care for counselees may partially be attributed to the relatively small number of counselees showing longterm psychopathological levels of distress, and most of them seem to cope relatively adequately with the DNA test result [7-16].

Thus, counselees do not receive help from a psychologist or social worker as standard care, probably because of these studies suggesting the absence of distress. Individual 
counselees may be referred for a broad range of reasons especially when obvious psychopathological levels of distress seem present (clinical experience). Referral may therefore not always meet the counselees' actual needs (cf., [17]). Thus, the policy and practice of referral to a psychologist or social worker seem to be based on the presence/absence of psychopathology in counselees. This strategy can be criticized for four reasons, which will lead us to the research questions of our empirical study. We will focus on literature about BRCA1/2 counseling, because the majority of all DNA tests are performed in genes for hereditary breast and/or ovarian cancer.

1. Unclear need - Authors such as Coyne et al. [7] seem to suggest that the presence/absence of psychopathology may imply that counselees do not actually need psychological care: 'it may be that the mental health issues associated with genetic testing for risk of breast and ovarian cancer are being overemphasized'. However, the counselees' self-reported request for psychological help may not correspond with psychopathological levels of distress as found by instruments measuring general distress. For instance, some patients may have questions/worry about their intention to undergo prophylactic mastectomy for which they need to receive help as this worry may be very disturbing in their lives, but may not necessarily have to reach levels of psychopathology [18]. Other patients may report psychopathology (e.g., depression or anxiety), but may not need psychological help because they have enough psychological and social coping resources. Thus, counselees may have needs or concerns besides psychopathology and which may directly result in distress. It may be advised to focus on the self-reported need of counselees instead of deriving their request for help from the presence/absence of psychopathology (cf., [17,19-21]). The relationship between psychopathology and the self-reported request for psychological help has not systematically been studied yet in genetic counseling.

2. Genetics-specific distress - Several researchers used general instruments for distress and psychopathology, and additionally, instruments dedicated for geneticsspecific concerns/distress have been developed [16]. Several recent studies used genetics-specific instruments, and these data suggest that many counselees may not experience psychopathological levels of distress but they may report feelings of vulnerability, stigma, uncertainty, and lack of perceived control, for which they may like to receive psychological help [22-25]. We call this 'distress' and not 'other needs', because this focuses on emotional aspects; that is, distress has been defined as 'a multifactorial unpleasant emotional experience of a psychological (cognitive, behavioral, emotional), social and/or spiritual nature that may interfere with the ability to cope effectively with cancer' [26]. The level of distress may be so high that a clinician may formally diagnose a psychopathological disorder. The relationship between genetics-specific distress and the self-reported request for help may need further exploration.
3. Other needs - It remains unclear why some counselees request for help and why others do not. Among various reasons may not only be psychopathology. For instance, counselees have also reported other psychological needs (apart from their request for information, which may be fulfilled by the genetic counselor); these needs may cause their request for receive psychological help, such as dealing with the emotional impact of cancer, uncertainty, vulnerability and feeling stigmatized, problems in making medical decisions, social isolation, familial context, previous experiences with cancer in themselves and/or in their relatives, having difficulties understanding, and misinterpreting the DNA test result [7,18,27-37]. Between $25 \%$ and $39 \%$ of all counselees have reported that their request for emotional support was not satisfied and they wished additional psychological help [31,38]. Thus, counselees report many reasons to receive help other than distress; this may have been overlooked because of the focus on distress. The reasons/predictors of the self-reported request for psychological help have not been systematically studied yet.

4. Existential concerns - Existential and spiritual concerns, such as the counselees' perceived certainty and purpose in life, and fundamental request for certainty about cancer and its heredity, have not systematically been studied, despite their reported importance for many counselees (e.g., [39-42]). Genetic counseling may inherently be regarded as an existential process, in which medical information is embedded in their sense of self and their lives in general [25,37].

These four considerations led us to the formulation of the following study questions:

1. How many counselees report that they need psychological help, and how many of them do actually receive psychological help?

2. In what way is this self-reported request for psychological help related to (i) psychopathology and (ii) non-psychopathology factors, that is, other needs, genetics-specific distress, and existential concerns?

\section{Method}

\section{Procedure and samples}

Eligible participants were women with breast and/or ovarian cancer who had requested a BRCA1/2 test in the period 2006-2009 at the departments of Clinical Genetics of the Leiden University Medical Center, the Maastricht University Medical Center, the University Medical Central Groningen, Erasmus Medical Center Rotterdam, or the VU Medical Center Amsterdam. Eligible counselees received two questionnaires: immediately after the first geneticcounseling session/intake (T1) and 3 months after the second genetic-counseling session in which the DNA test result was disclosed (T2, i.e., 4-6 months after T1). Usually, genetic counselors disclosed the following information: DNA test result category, heredity likelihood, cancer risks for female relatives and for the counselee, and risk management options (surgery, surveillance) for relatives and counselees, including the possibility for relatives 
to undergo DNA testing when applicable. More information on the procedure and sample, such as informed consent and approval by all relevant medical ethical committees, are described elsewhere $[25,43]$.

\section{Instruments}

We selected the instruments on the basis of suggestions in the literature as described in the Introduction (Table 1).

The request for psychological help was measured on a 7-point Likert scale ranging from 'no need' (1) to 'strong need' (7): 'Would you like to talk with a psychologist or social worker?' (cf., [17,19-21]). Other formulations were also used, and we also asked about the counselees' intentions to actually ask for help; these formulations did not lead to significant differences, and therefore, we only used this question. These questions about the request for psychological help were part of 15 questions by which we asked the counselees' request to receive help or referral to several professions (e.g., surgeon, radiology); at follow-up, dichotomic questions measured whether they had actually received help from these professions.

The level of psychopathology was estimated with several instruments measuring psychopathology, to be in line with previous studies in which these psychopathology instruments were used. We assumed that genetic counseling may increase a general feeling of psychopathology and that it may not make sense to specify the types of psychopathology. For this reason, and because of parsimony and limited textual space, we used principal component analyses (PCAs) with Varimax rotation, and we decided on the number of factors on the basis of the eigenvalues, scree plot, Variance-Explained-For $\left(\mathrm{VAF} / R^{2}\right)$, interpretability, and Cronbach's alpha. Unpresented PCA results can be requested from the authors. For each participant, we calculated scores on the created factors by using regression analyses. PCA suggested 'negativity' and 'worry' as two factors underlying the scores on the Hospital Anxiety and Depression Scale, Positive Affect Negative Affect Scale, Lerman's Cancer Worry Scale, and Impact of Events Scale [44-48]. Negativity measured general as well as cancer-specific negative emotions. Worry measured general and cancer-specific worry. Analyses without data reduction yielded similar results (unpresented).

We decided to measure other needs similar to the aforementioned studies. The intentions to undergo surgery or surveillance during the coming 6 months were measured on 7-point Likert scales. The counselees' interpretation of their own risks and of the likelihood that cancer is heritable in the family was measured $[40,43,49]$. The familial context was measured with the openness to discuss hereditary cancer in the nuclear family and the family of origin [34], the number of affected and deceased relatives (collected from medical files), and the number of children. The perceived impact of cancer on their lives was measured with the Illness Perception Questionnaire (IPQ; [50]); similar items of the IPQ assessed whether other life events during the last 6 months had influenced their lives. We used several questions regarding the medical history and sociodemographics as frequently used [51]. Geneticsspecific distress was measured with Esplen's BRCA-related self-concept scale; PCA confirmed that this scale consisted of feeling stigmatized, feeling vulnerable to developing cancer, and experiencing reduced mastery over cancer [24,35]. The 8-item Life Changes Questionnaire was used to measure the impact of DNA testing on several life domains; PCA indicated that two factors were measured by this scale: medical changes and psychological-existential changes [49]. Existential concerns were measured with reliable, valid scales: Ryff's eudaimonic well-being scale [52], optimism [53], and the Unfulfilled Need for Certainty Scale [49].

\section{Statistics}

\section{Question 1}

We calculated the number and percentage of counselees with a request for psychological help at T1 and T2 (i.e., scores of 5, 6, or 7 on the 7-point Likert scale) and the number/percentage of counselees who reported actually receiving help.

\section{Question 2}

We used Pearson's correlations (cf., beta in simple regression analyses) to correlate the counselees' selfreported request for psychological help with the predictors in Table 1. Subsequently, we performed partial correlation analyses to correct these relationships for the level of psychopathology (i.e., negativity and worry); by doing this, we tried to see the unique effects of these nonpsychopathology predictors on the self-reported request for help.

For presentation purposes, we present only significant correlations in the text; non-significant relationships and exact figures can be found in the tables. Using T1 scores as covariate in analyses of T2 scores did not lead to different scores and are therefore not presented. Multiple regression analysis was not possible because of multicollinearity and conceptual overlap of variables; structural equation modeling was impossible because of the large number of estimated parameters relative to the sample size. Only moderate or large effects $(R>0.20, p<0.01)$ are presented. We did not perform a stricter correction of statistical errors such as Bonferroni, because we wanted to balance two arguments. On the one hand, this is an explorative study with rather specific expectations about the direction of most correlations, which suggests using high $p$-values (e.g., $p<0.10$ ) to avoid type II statistical error, that is, rejecting a hypothesis when it is actually true. On the other hand, we performed many tests, which increased the possibility of type I error, that is, accepting our hypothesis when it is actually false; therefore, we used $p<0.01$ as significance criterion. We did not include information about the actually communicated DNA test result $[25,49]$, because neither did this correlate with the request for help nor was it a significant covariate or confounder. We call a correlation small when $R<0.23$, moderate when $R=0.24-0.26$, and large when $R>0.37$.

\section{Results}

\section{Description of sample}

We approached 654 women who had undergone BRCA1/2 testing. Of them, $467(71 \%)$ filled in the $\mathrm{T} 1$ 
Table I. Overview of predictors and contextual factors, including instruments used in our analyses

\begin{tabular}{|c|c|c|c|c|}
\hline & Instrument & Scales & $\begin{array}{l}\text { Range of } \\
\text { total scores }\end{array}$ & $\begin{array}{l}\text { Explained } \\
\text { variance if } \\
\text { PCA; alpha }\end{array}$ \\
\hline Psychopathology & $\begin{array}{l}\text { Hospital Anxiety and Depression Scale } \\
\text { Impact of Events Scale; Positive Affect } \\
\text { Negative Affect Scale; Lerman's Cancer } \\
\text { Worry [44-48] (TI, T2) }\end{array}$ & $\begin{array}{l}2 \text { PCA factors: I. Negativity with strong values on: anxiety, } \\
\text { depression, positive and negative affects; } 2 \text {. Worry } \\
\text { with strong values on: cancer worry, avoidance, } \\
\text { intrusions, anxiety }\end{array}$ & $\begin{array}{l}\text { Individual scores } \\
\text { calculated with } \\
\text { regression (overall: } \\
m=0, s d=1 \text { ) }\end{array}$ & $\begin{array}{l}0.40 ; 0.90 \\
0.37 ; 0.87\end{array}$ \\
\hline \multirow[t]{7}{*}{ Other needs } & $\begin{array}{l}\text { Medical decisions intended in the next } \\
6 \text { months (PCA) }(\mathrm{TI}, \mathrm{T} 2)\end{array}$ & $\begin{array}{l}\text { Composite scales: I. Intended breast surveillance ( } 3 \text { items), } \\
\text { i.e., breast self-examination, surveillance of breasts by } \\
\text { physician, and mammography; } 2 \text {. intended mastectomy; } \\
\text { 3. intended surveillance of ovaries ( } 2 \text { items): surveillance } \\
\text { by physician; blood sample; } 4 \text {. intended bilateral } \\
\text { salpingo-oophorectomy }\end{array}$ & $\begin{array}{l}\text { Individual regression } \\
\text { scores (overall: } \\
m=0, s d=1 \text { ) }\end{array}$ & $\begin{array}{l}0.27 ; 0.87 \\
0.27 ; 0.87 \\
0.19 ; 0.90\end{array}$ \\
\hline & Interpretations $[37,40,49,76]$ & $\begin{array}{l}\text { I. Interpretation of own cancer risks (i.e., thoughts } \\
\text { and feelings regardless of what the genetic counselor has } \\
\text { communicated). } 2 \text {. Interpretation of the likelihood that } \\
\text { cancer is heritable in the family. 3. Extent of accuracy of } \\
\text { interpretation of own cancer risks as indicated by } \\
\text { difference between the actually communicated risks } \\
\text { (derived from medical files) and the interpretation of } \\
\text { one's own risks (larger score = more inaccurate) }\end{array}$ & $\begin{array}{l}\text { I-7 (not likely/low } \\
\text { risk-very likely/ } \\
\text { high risk) }\end{array}$ & Single items \\
\hline & $\begin{array}{l}\text { Family relationships: openness to discuss } \\
\text { hereditary cancer in the nuclear family [34]; } \\
\text { information }(T 1, T 2)\end{array}$ & $\begin{array}{l}\text { 1. Openness to discuss hereditary cancer in the } \\
\text { nuclear family. 2. Openness in family from origin. } \\
\text { 3. Pedigree information in medical files: numbers, percentages, } \\
\text { and years of with cancer-affected and deceased Ist, 2nd, } \\
\text { and/or 3rd degree relatives }\end{array}$ & $\begin{array}{l}\text { I: } 7-35 \text { (closed- } \\
\text { open). } 2: 7-35 \\
\text { (closed-open). } \\
3: \%, n, \text { year }\end{array}$ & $\begin{array}{l}\text { Composite scores, } \\
\text { no PCA }\end{array}$ \\
\hline & $\begin{array}{l}\text { Illness perception questionnaire, IPQ-R } \\
\text { [50] (TI, T2) }\end{array}$ & $\begin{array}{l}\text { Single items: influence of cancer on life, duration of cancer, } \\
\text { control over cancer, treatment control over cancer, physical } \\
\text { complaints, worry about cancer, understanding cancer, } \\
\text { influence from cancer on mood }\end{array}$ & I-10 (few-many) & Single items \\
\hline & $\begin{array}{l}\text { Influence from other life events (items from } \\
\text { the IPQ were used) (TI, T2) }\end{array}$ & $\begin{array}{l}\text { Single items: influence of events on life, worry about } \\
\text { events, influence from event on mood }\end{array}$ & I-10 (few-many) & Single items \\
\hline & Medical history $(\mathrm{TI}, \mathrm{T} 2)$ & $\begin{array}{l}\text { I. Breast or ovarian cancer. 2. Metastases. 3. Kind of } \\
\text { cancer treatment: mastectomy, bilateral salpingo- } \\
\text { oophorectomy, chemotherapy, radiotherapy, other } \\
\text { therapy. 4. Years since disclosure of cancer } \\
\text { diagnoses, metastases, treatment and of genetic counseling }\end{array}$ & $0-1$ (no-yes) & Single items \\
\hline & Sociodemographics (TI) & $\begin{array}{l}\text { I. Living together with a partner. 2. Having children. } \\
\text { 3. Number of children, sons, daughters. 4. Number of children } \\
\text { at home. 5. Being religious. 6. Having a job. 7. Number of } \\
\text { hours of job. 8. Educational level ranging from none } \\
\text { (0)-university (7). 9. Age }\end{array}$ & $0-1$ (no-yes) or $\mathrm{N}$ & Single items \\
\hline \multirow[t]{2}{*}{$\begin{array}{l}\text { Genetics-specific } \\
\text { distress }\end{array}$} & BRCA-related self-concept [24,35] (TI, T2) & $\begin{array}{l}\text { PCA confirmed } 3 \text { scales: I. Stigma (7 items). } \\
\text { 2. Vulnerability ( } 5 \text { items). 3. Lack of mastery ( } 4 \text { items) }\end{array}$ & $\begin{array}{l}7-49 \text { (none-a lot); } \\
5-35 \text { (none-a lot); } \\
4-28 \text { (none-a lot) }\end{array}$ & $\begin{array}{l}0.30 ; 0.75 \\
0.22 ; 0.73 \\
0.19 ; 0.59\end{array}$ \\
\hline & Life Changes Questionnaire [37,40] (TI, T2) & $\begin{array}{l}\text { Composite scales confirmed by PCA: changes in } \\
\text { life because DNA test result attributed to } \\
\text { DNA testing: ( } 1 \text { ) psychological-existential changes } \\
\text { (3 items), (2) physical-medical changes ( } 5 \text { items) }\end{array}$ & $\begin{array}{l}3-15 \text { (none-a lot); } \\
7-35 \text { (none-a lot) }\end{array}$ & $\begin{array}{l}0.20 ; 0.67 \\
0.40 ; 0.83\end{array}$ \\
\hline \multirow[t]{3}{*}{$\begin{array}{l}\text { Existential } \\
\text { concerns }\end{array}$} & $\begin{array}{l}\text { Ryff's eudaimonic well-being scales } \\
{[5 \mathrm{I}](\mathrm{T} I, \mathrm{~T} 2)}\end{array}$ & $\begin{array}{l}\text { Composite scales: I. Environmental mastery. } \\
\text { 2. Purpose in life. 3. Self-acceptance. 4. Autonomy. } \\
\text { 5. Personal growth. 6. Enjoying relationships. } \\
\text { 7. Vitality. 8. Inner strength }\end{array}$ & 6-36 (little-much) & Composite scales \\
\hline & Revised life orientation scale [52] (TI, T2) & Optimism; composite scale of 10 items & $\begin{array}{l}\text { I0-50 (not/very } \\
\text { optimistic) }\end{array}$ & Composite scale \\
\hline & $\begin{array}{l}\text { Unfulfilled need for certainty scale } \\
\text { [49] (TI, T2) }\end{array}$ & $\begin{array}{l}\text { Unfulfilled need for certainty about: DNA test } \\
\text { result, heredity, cancer, self (unfulfilled = need for } \\
\text { certainty is larger than perceived certainty; fulfilled = } \\
\text { perceived certainty is larger than need for certainty) }\end{array}$ & $\begin{array}{l}\text { DNA: } 6-42 \\
\text { (fulfilled-unfulfilled). } \\
\text { Other: } 5-35 \\
\text { (fulfilled-unfulfilled) }\end{array}$ & $\begin{array}{l}0.88 ; 0.85 \\
0.86 ; 0.89 \\
0.85 ; 0.87 \\
0.84 ; 0.85\end{array}$ \\
\hline
\end{tabular}

Data in bold show significance in the analyses of TI and/or T2 (Table 4).

questionnaire, and subsequently, 248 (53\%) filled in the T2 questionnaire after disclosure of pathogenic mutation results $(n=30)$, uninformative results $(n=202)$, or unclassified variants $(n=16)$ (no significant differences were found in the outcome variables in this study and are therefore not discussed separately in the text). See Table 2; more information is published elsewhere $[25,37,49]$.

\section{Description of the self-reported request for help}

After the intake (T1), 27\% of all counselees reported a request for psychological help (score $\geq 5$ on a 7-point scale; mean, $m=3.6$; standard deviation, $s d=1.5$ ). After the disclosure of the DNA test (T2), 20\% needed to receive psychological help $(m=3.2, s d=1.3)$. At T1, 20\% of all counselees received help (which is $34 \%$ of all 
Table 2. Description of study population

\begin{tabular}{|c|c|c|c|c|c|}
\hline & Variable & $n$ & $\%$ & Mean & $S D$ \\
\hline \multirow[t]{2}{*}{ Participation } & Returned questionnaire after intake & 458 & 68 & & \\
\hline & Returned questionnaire after DNA result & 248 & 54 & & \\
\hline & Breast cancer & 234 & 94 & & \\
\hline & Ovarian cancer & 14 & 6 & & \\
\hline & Metastatic cancer & 64 & 26 & & \\
\hline & Mastectomy (BM) & 139 & 56 & & \\
\hline & Bilateral salpingo-oophorectomy (BSO) & 53 & 11 & & \\
\hline \multirow[t]{6}{*}{ Sociodemographics } & Age & & & 56 & 23 \\
\hline & Attended high school or higher & 105 & 42 & & \\
\hline & Being married & 207 & 84 & & \\
\hline & Having children & 216 & 87 & & \\
\hline & Having daughter(s) & 171 & 69 & & \\
\hline & Having son(s) & $|5|$ & 61 & & \\
\hline
\end{tabular}

counselees with a request for help), and at $\mathrm{T} 24 \%$ received help (29\% of those with a need). See Table 3.

\section{Predictors of the self-reported request for help}

This paragraph describes the significant predictors of the request for help; Table 4 shows the figures for the significant outcomes and also the non-significant predictors.

The psychopathological factors 'negativity' and 'worry' correlated moderately/strongly $(R=0.34,0.44)$ with the request for psychological help at $\mathrm{T} 1$ and $\mathrm{T} 2$ (see figures in Table 4).

One other need correlated moderately/strongly $(R=0.24-0.44)$ with this need at T1 and/or T2, also after correction for the level of psychopathology: intention to undergo mastectomy or bilateral salpingo-oophorectomy. Several other needs correlated moderately $(R=0.20,0.36)$ with this request for help: influence from cancer, worry about cancer and influence from cancer on mood, and number of children at home; these needs became nonsignificant at $\mathrm{T} 1$ when corrected for the level of psychopathology. The counselees' interpretation of their cancer risks, heredity likelihood, and the accuracy of the interpretation of their own risks did not significantly correlate with the request for help at T1; the interpretations correlated moderately with the need at $\mathrm{T} 2(R=0.20,0.28)$, and the accuracy of the interpretation of their own risks correlated strongly $(R=0.37)$ with the request for help at $\mathrm{T} 2$ when corrected for the level of psychopathology. Family relationships, medical history, and other sociodemographic variables did not significantly correlate with the request for help. Open

Table 3. Overview of the number (\%) of counselees with a request for psychological help and the number who actually receives psychological help

\begin{tabular}{|c|c|c|}
\hline & $\begin{array}{c}\text { Request for } \\
\text { psychological help }\end{array}$ & $\begin{array}{l}\text { Actual receipt of } \\
\text { psychological help }\end{array}$ \\
\hline & N (\%/sample) & $\begin{array}{c}N \text { (\%/sample; \%/request } \\
\text { for help) }\end{array}$ \\
\hline After the intake session & I0| (27\%) & $34(20 \% ; 34 \%)$ \\
\hline $\begin{array}{l}\text { After the DNA test } \\
\text { result session }\end{array}$ & $34(16 \%)$ & II (4\%; 29\%) \\
\hline
\end{tabular}

$N$ may differ per cell because of missing values.

'Measured as 'I need to receive psychological help' on a 7-point scale (not-much); much is defined as scores 5,6 , or 7 . communication style with the family correlated moderately with the request for help $(R=-0.20,-0.29)$.

The genetics-specific distress-variables vulnerability, stigma, and mastery correlated moderately/strongly with the request for help at $\mathrm{T} 1$ and $\mathrm{T} 2(R=0.24,0.43)$. Medical-physical and psychological-existential changes correlated moderately with the need at T2 $(R=0.25,0.26)$.

Most existential concerns correlated moderately with the request for help at $\mathrm{T} 1$ and $\mathrm{T} 2(R=0.20,0.37)$ : mastery, purpose self-acceptance, personal, growth, vitality, and need for certainty about the DNA test result, heredity, cancer, and self. At T1, the effects of all existential concerns became small or not significant when corrected for the level of psychopathology; at T2, the effects remained moderate after correction.

\section{Discussion}

The results suggest that the counselees' self-reported request for help in genetic counseling is not only determined by the level of their psychopathology, because both were only correlated between 0.34 and 0.44 . Thus, the presence of psychopathology may not necessarily imply a request for psychological help, and a request for help may not only be due to psychopathology. This request for help seems to be a multi-factorial phenomenon.

1. Other needs: A large part of the counselees' request for help was not correlated with psychopathology. 'Other needs' as indicated by previous studies mentioned in the Introduction section also correlated with the counselees' request for help. Examples of strong correlations were the intention to undergo surgery, the inaccuracy of the counselees' interpretation of the DNA test result, the impact of cancer, and communication difficulties with the family. Life events other than cancer and DNA testing did not influence the counselees' request for help. Thus, counselees may need to receive psychological help regarding these cancer-related and genetic-related topics during genetic counseling.

2. Genetics-specific distress: Compared with psychopathology, distress measured with genetics-specific instruments was an equally strong predictor of the counselees' self-reported request for help, which suggests that these genetics-specific instruments were 
Table 4. Significant Pearson's correlations between the self-reported need to receive psychological help, and psychopathology, other needs, genetics-specific distress, and existential concerns

\begin{tabular}{|c|c|c|c|c|c|c|}
\hline \multirow[b]{2}{*}{ Variable } & & & \multicolumn{2}{|c|}{ TI } & \multicolumn{2}{|c|}{ T2 } \\
\hline & & & $\boldsymbol{R}$ & Partial $R$ & $\boldsymbol{R}$ & Partial $R$ \\
\hline \multirow[t]{2}{*}{ Psychopathology } & & Negativity & 0.34 & $\mathrm{n} / \mathrm{a}$ & 0.34 & $\mathrm{n} / \mathrm{a}$ \\
\hline & & Worry & 0.44 & $\mathrm{n} / \mathrm{a}$ & 0.38 & $\mathrm{n} / \mathrm{a}$ \\
\hline \multirow[t]{10}{*}{ Other needs } & Medical intentions & Intention mastectomy & 0.24 & 0.24 & 0.24 & 0.44 \\
\hline & & Intention bilateral salpingo-oophorectomy & 0.31 & 0.39 & 0.24 & 0.39 \\
\hline & Interpretation & Inaccuracy of interpretation of own risks & ns & ns & 0.27 & 0.37 \\
\hline & & Interpretation of heredity likelihood & ns & ns & 0.21 & 0.20 \\
\hline & Family & Openness with nuclear family & -0.29 & -0.24 & -0.21 & -0.20 \\
\hline & & Openness with family of origin & -0.20 & -0.20 & -0.23 & -0.21 \\
\hline & Impact of cancer & Influence of cancer on life & 0.36 & ns & 0.35 & 0.26 \\
\hline & & Worry & 0.36 & ns & 0.32 & 0.21 \\
\hline & & Influence on mood & 0.40 & ns & 0.29 & 0.28 \\
\hline & Sociodemographics & Number of children living at home & 0.28 & ns & 0.23 & ns \\
\hline \multirow{3}{*}{ Genetics-specific distress } & & Lack of mastery & 0.33 & 0.30 & 0.24 & 0.26 \\
\hline & Life changes since DNA test result & Medical changes & $\mathrm{n} / \mathrm{a}$ & $\mathrm{n} / \mathrm{a}$ & 27 & 0.25 \\
\hline & & Psychological-existential changes & $\mathrm{n} / \mathrm{a}$ & $\mathrm{n} / \mathrm{a}$ & 0.27 & 0.26 \\
\hline \multirow[t]{9}{*}{ Existential concerns } & Ryff's well-being scale & Mastery & -0.29 & ns & -0.26 & -0.21 \\
\hline & & Purpose & -0.22 & ns & -0.30 & -30 \\
\hline & & Self-acceptance & -0.25 & ns & -0.28 & -0.28 \\
\hline & & Personal growth & -0.20 & -0.22 & -0.25 & -0.25 \\
\hline & & Vitality & -0.29 & ns & -0.24 & -0.28 \\
\hline & Unfulfilled need for certainty & Unfulfilled need for certainty about DNA result & 0.20 & ns & 0.24 & 0.25 \\
\hline & & Unfulfilled need for certainty about heredity & 0.21 & ns & 0.27 & 0.31 \\
\hline & & Unfulfilled need for certainty about cancer & 37 & 0.23 & 0.34 & 0.34 \\
\hline & & Unfulfilled need for certainty about self & 0.37 & 0.20 & 0.30 & 0.30 \\
\hline
\end{tabular}

$R$, Pearson's correlation, all $p<0.0 I$ and $R>0.20$ (not significant variables are shown in Table 2); $T I$, measurement after the first intake session; $T 2$, measurement after the disclosure of the DNA test result; ns, not significant; n/a, not applicable; partial $R$, partial correlations, that is, corrected for the level of anxiety and negativity.

as useful in identifying counselees who need help; however, asking counselees about distress may yield different answers than asking them about their request for psychosocial help [7,24,35].

3. Existential concerns: Existential concerns correlated moderately with the counselees' request for help. This may suggest that counselees who experience existential/ spiritual problems may want to receive help regarding these questions, for example, purpose in life and selfacceptance. Counselees may also want to receive help when they feel that the current situation gives them less certainty than they want to have, that is, when they feel an unfulfilled request for certainty regarding the DNA test result, heredity, cancer, and themselves. These findings are in line with several studies showing that meaning, existential issues, and spiritual wellbeing are important for cancer patients to adjust to their cancer [54-59]. Cancer patients who do not experience meaning in life seem to be less adjusted to cancer, experience lower well-being, and report more distress and more depression [60-65]. Patients who are not able to reengage in finding meaning in life may also experience less positive mood [66].

4. Corrections: When we corrected the correlations for the level of psychopathology at T1, several other needs and existential concerns became not significant. However, at $\mathrm{T} 2$, these other needs and existential concerns remained significant without reduction in effect sizes. This may be explained by the fact that the level of psychopathology can be expected to be largest in the period between the intake session and the disclosure of the DNA test result and immediately after the disclosure; in the long term, psychopathology may decrease (cf., [16]). This may suggest that in the period of waiting for the DNA test result, psychopathology may actually be a good predictor of the counselees' request for help, but it may not be several months after disclosure of the DNA result, when the focus is less on psychopathology and more other needs/concerns. Later in time, psychopathology disappears but other needs and existential concerns remain, possibly because counselees only start understanding the consequences of the DNA test result on the long term.

\section{Implications}

Because of logistic reasons, we could not perform a baseline measurement (T0) of the request for help and could not use complex statistics such as structural equation modeling. These could be included in future studies. Other formulations may be used to ask counselees about their request for help, and the relationships between need, intention, and actual receipt of psychological help may be explored. The role of subjective bias and the counselees' skills to report their psychological needs should be examined.

A remarkable finding was that only one-third of all counselees who reported a request for receiving help from a psychologist or social worker had actually received such help. This indicates that counselees should not only be 
referred on the basis of (the counselors' interpretation of) psychopathology. Genetic counselors could offer referral to a psychologist or social worker not only when psychopathology is present but also when other needs, geneticsspecific distress, or existential concerns arise.

As is already frequently happening, these themes may be discussed during a reciprocal dialogue between the genetic counselor and counselee [67]. In this conversation, the meaning, interpretation, and consequences of the DNA test result for the counselees may be explored [25,36,37,43,49,68].

Counselees may not ask for psychological help for reasons other than psychopathology because they may be anxious and/or think in stereotypes [69]. Therefore, a genetic counselor may explicitly explain to counselees for what kind of reasons they could be referred to a psychologist or social worker, for example, distress, difficult decision-making, telling the family, difficulties in living with uncertainty, or creating their identity as (non)-mutation carrier. In the context of such an explanation, counselees may be asked the simple question of whether they would like to receive support for any of these reasons.

Additionally, screening instruments may be used to identify counselees who may need to receive psychological help. However, many instruments seem to focus mainly on psychopathology or only ask in non-specific terms about other needs and existential concerns. New items may be developed to measure this. Our results suggest that it may not be useful to make a 'personal profile' of counselees who need to receive psychological help, for example, on the basis of the actually communicated DNA test result, medical history, or sociodemographic variables; these variables were uncorrelated with the selfreported request for help (except for having many children still living at home; cf., [51]). One may simply ask the question: 'Would you like to speak with a social worker or psychologist?' (as many counselors do) [17,19-21].

In the Dutch context of this research, when counselees asked for psychological help, they could receive help from a psychologist or social worker with specific expertise in genetic counseling. Such specialized psychological help may not always be possible in all countries; in these situations, the counselee may ask for help from a psychologist or social worker without any knowledge about genetic counseling. It is unclear whether this general psychological help is as effective as the specialized psychological help. Clinical experience suggests that some psychological issues may be easier to understand and addressed by specialized psychological help, but more research about this is needed.

There may be many psychotherapeutic interventions to help counselees with their concerns during genetic counseling. Decision-making interventions-for example, 'decision aids' - may help making decisions between screening and preventive surgery (e.g., [70]). Help may be offered in communicating DNA test results to the family, for example, by leaflets or by direct communication between genetic counselor and the counselees' relatives $[36,68]$. The counselees' interpretations of the DNA test result may be discussed, and consequences for their emotional life may be explored [25,37,49]. Existential concerns may be targeted with existential and spiritual interventions [71-73]. The genetic risks - and the wish to know more about these, and the worries evoked by these-may be seen and relativized from the general context of the counselees' lives: life always includes risks and uncertainties, and other activities, such as skydiving, may include larger risks without receiving extensive counseling. The main thread of all psychological interventions may be to help counselees living with 'dual realities' $[25,37,74]$ That is, on the one hand, they may be stimulated to acknowledge the genetic reality, and their feelings of uncertainty and vulnerability regarding the DNA test result. On the other hand, they may be helped in finding psychological and social resources to regain (to some extent) a feeling of certainty and invulnerability, to be able to live their daily lives in a meaningful way $[25,37,74,75]$.

\section{References}

1. Resta R, Biesecker BB, Bennett RL et al. A new definition of genetic counseling: national society of genetic counselors' task force report. J Genet Couns 2006;15(2):77-83.

2. Rantanen E, Hietala M, Kristoffersson U et al. What is ideal genetic counselling? A survey of current international guidelines. Eur $J$ Hum Genet 2008;16:7.

3. Kessler S. The psychological paradigm shift in genetic counseling. Soc Biol 1980;27(3):167-185.

4. Benazon NR, Coyne JC, Calzone KA, Weber BL. Why not to screen high-risk women anticipating BRCA1/BRCA2 testing for psychological distress. J Consult Clin Psychol 2002;70(1):258-258.

5. Resta R. The historical perspective: Sheldon Reed and 50 years of genetic counseling. $J$ Genet Couns 1997;6(4):375-377.

6. Resta R. Defining and redefining the scope and goals of genetic counseling. Am J Med Genet C Semin Med Genet 2006;142C: 269-275.

7. Coyne JC, Kruus L, Racioppo M, Calzone KA, Armstrong K. What do ratings of cancer-specific distress mean among women at high risk of breast and ovarian cancer? Am $J$ Med Genet A 2003;116A(3):222-228.

8. Biesecker B. Adaptation to living with a genetic condition or risk: a mini review. Clin Genet 2008;74:401-407.

9. Coyne JC, Benazon NR, Gaba CG, Calzone $\mathrm{K}$, Weber, BL. Distress and psychiatric morbidity among women from high-risk breast and ovarian cancer families. $J$ Consult Clin Psychol 2000;68(5):864-874.

10. Meiser B, Halliday JL. What is the impact of genetic counselling in women at increased risk of developing hereditary breast cancer? A meta-analytic review. Soc Sci Med 2002;54(10):1463-1470.

11. Butow PN, Lobb EA, Meiser B, Barratt A, Tucker KM. Psychological outcomes and risk perception after genetic testing and counselling in breast cancer: a systematic review. Med J Aust 2003;178(2):77-81.

12. Meiser B. Psychological impact of genetic testing for cancer susceptibility: an update of the literature. Psycho-Oncology 2005; 14(12):1060-1074.

13. Braithwaite D, Emery J, Walter F, Prevost AT, Sutton S. Psychological impact of genetic counseling for familial cancer: a systematic review and meta-analysis. Fam Cancer 2006;5(1):61-75.

14. Schlich-Bakker KJ, ten Kroode HFJ, Ausems MGEM. A literature review of the psychological impact of genetic testing on breast cancer patients. Patient Educ Couns 2006; 62(1):13-20.

15. Heshka JT, Palleschi C, Howley H, Wilson B, Wells PS. A systematic review of perceived risks, psychological and behavioral impacts of genetic testing. Genet Med 2008;10(1): 19-32.

16. Hamilton JG, Lobel M, Moyer A. Emotional distress following genetic testing for hereditary breast and ovarian cancer: a metaanalytic review. Health Psychol 2009;28(4): 510-518.

17. Van Scheppingen C, Schroevers M, Smink A et al. Does screening for distress efficiently uncover meetable unmet needs in cancer patients? Psycho-Oncology 2011;20(6):655-663.

18. Tan BM, Menke-Pluymers MBE, Van Gool AR et al. Standard psychological consultations and follow up for women at increased risk of hereditary breast cancer considering prophylactic mastectomy. Hered Cancer Clin Pract. 2009 2009;7(1):6. 
19. Garssen B, De Kok E. How useful is a screening instrument? Psycho-Oncology 2008;17:3.

20. Baker-Glenn EA, Park B, Granger L, Symonds P, Mitchell AJ. Desire for psychological support in cancer patients with depression or distress: validation of a simple help question. Psycho-Oncology 2010.

21. Garssen B. Screening for emotional distress in cancer patients: a systematic review of assessment instruments. J Natl Cancer Inst 2010;102:3.

22. Berkenstadt $M$, Shiloh S, Barkai G, Katznelson MBM, Goldman B. Perceived personal control (PPC): a new concept in measuring outcome of genetic counseling. Am J Med Genet 1999;82(1):53-59.

23. Esplen MJ, Stuckless N, Hunter J et al. The development of a self-concept scale for BRCA1 and BRCA2 carriers. Psycho-Oncology 2000; 9(5):S4-S4.

24. Esplen MJ, Stuckless N, Hunter J et al. The BRCA Self-Concept Scale: a new instrument to measure self-concept in BRCA1/2 mutation carriers. Psycho-Oncology 2009. DOI 10.1002/ pon. 1498.

25. Vos J. In Opening the psychological black box in genetic counseling. A counseleeoriented, integrative approach on the impact of DNA-testing for breast and ovarian cancer on the lives of counselees. $\mathrm{PhD}$ thesis. Leiden University: Leiden, 2011.

26. NCCN. NCCN Clinical practice guidelines in oncology: distress management, 2010.

27. Deane KA, Degner LF. Information needs, uncertainty, and anxiety in women who had a breast biopsy with benign outcome. Cancer Nurs 1998;21(2):117-126.

28. Hopwood P, Keeling F, Long A, Pool C, Evans G, Howell A. Psychological support needs for women at high genetic risk of breast cancer: some preliminary indicators. PsychoOncology 1998;7(5):402-412.

29. Thewes B, Butow P, Girgis A, Pendlebury S. Assessment of unmet needs among survivors of breast cancer. $J$ Psychosoc Oncol 2004a;22(1):51-73.

30. Thewes B, Butow P, Girgis A, Pendlebury S. The psychosocial needs of breast cancer survivors; a qualitative study of the shared and unique needs of younger versus older survivors. Psycho-Oncology 2004b; 13(3):177-189.

31. Pieterse, AH. Counselees' needs and their reflection in cancer genetic counselling. Thesis, University of Utrecht, Netherlands, 2005.

32. Vivar CG, McQueen A. Informational and emotional needs of long-term survivors of breast cancer. $J$ Adv Nurs 2005;51(5): 520-528.

33. Shiloh S, Gerad L, Goldman B. Patient's information needs and decision-making processes: what can be learned from genetic counselees? Health Psychol 2006;25(2): 211-219.

34. van Oostrom I, Meijers-Heijboer EJ, Duivenvoorden $\mathrm{H}$ et al. Family system characteristics and psychological adjustment to cancer susceptibility genetic testing: a prospective study. Clin Genet 2007;71(1):35-42.

35. Den Heijer M, Vos J, Seynaeve C et al. The impact of social and personal resources on psychological distress in women at risk for hereditary breast cancer. Psycho-Oncology 2012;21(2):153-160.
36. Vos J, Oosterwijk JC, Gomez-Garcia EB, et al. Perceiving cancer-risks and heredity-likelihood in genetic-counseling: the analysis of the counselees' recollections and interpretations of BRCA1/2-test results. Clin Genet 2011;79(3): 207-218.

37. Vos J, Menko F, Oosterwijk JC et al. A counselee-oriented perspective on riskcommunication in genetic-counseling: explaining the inaccuracy of the counselees' risk-perception. Genet Med 2011;13:800-811.

38. Di Prospero LS, Seminsky M, Honeyford J et al. Psychosocial issues following a positive result of genetic testing for BRCA1 and BRCA2 mutations: findings from a focus group and a needs-assessment survey. Can Med Assoc J 2001;164(7):1005-1009.

39. Kavanagh AM, Broom DH. Embodied risk: my body, myself? Soc Sci Med 1998; 46(3):437-444.

40. Vos J, Otten W, van Asperen C, Jansen A, Menko F, Tibben A. The counsellees' view of an unclassified variant in BRCA1/2: recall, interpretation, and impact on life. PsychoOncology 2008;17(8):822-830.

41. Klitzman R. "Am I my genes?": questions of identity among individuals confronting genetic disease. Genet Med 2009;11(12):880-889.

42. Robertson A. Embodying risk, embodying political rationality: women's accounts of risks for breast cancer. Health, Risk Soc 2010;2(2):219-235.

43. Vos J, Oosterwijk JC, Gomez-Garcia EB et al. Exploring the short-term impact of DNAtesting: the counselees' perception matters, the actual BRCA1/2-result does not. Pat Educ Counsel 2012;86(2):239-251.

44. Horowitz M, Wilner N, Alvarez W. Impact of event scale-measure of subjective stress. Psychosom Med 1979;41(3):209-218.

45. Zigmond AS, Snaith RP. The Hospital Anxiety and Depression Scale. Acta Psychiatr Scand 1983;67(6):361-370.

46. Lerman C, Trock B, Rimer BK, Jepson C, Brody D, Boyce A. Psychological SideEffects of Breast-Cancer Screening. Health Psychol 1991;10(4):259-267.

47. Spinhoven P. A validation study of the Hospital Anxiety and Depression Scale (HADS) in different groups of Dutch subjects. Psychol Med 1997;27(2):363-370.

48. Kasparian NA, Wakefield CE, Meiser B. Assessment of psychosocial outcomes in genetic counseling research: an overview of available measurement scales. J Genet Couns 2007;16(693):712.

49. Vos J, Menko FH, Oosterwijk JC et al. Genetic counseling does not fulfill the counseles' need for certainty in hereditary breast/ ovarian cancer families: an explorative assessment. Psycho-Oncology (in press).

50. Moss-Morris R, Weinman J, Petrie K, Hornec R, Cameron L, Buick D. The Revised Illness Perception Questionnaire (IPQ-R). Psychol Health 2002;17(1):1-16.

51. van Dijk S. In Chances and choices. Psychological impact of genetic counselling and DNA testing for breast cancer, focusing on women who receive an uninformative result. Dissertation, Leiden University: Netherlands, 2006.

52. van Dierendonck D. The construct validity of Ryff's Scales of Psychological Well-being and its extension with spiritual well-being. Pers Individ Dif 2004;36(3):629-643.
53. Scheier MF, Carver CS, Bridges MW Distinguishing optimism from neuroticism (and trait anxiety, self-mastery, and selfesteem) - a reevaluation of the life orientation test. J Pers Soc Psychol 1994;67(6):1063-1078.

54. Fife BL. The conceptualization of meaning in illness. Soc Sci Med 1994;38(2):309-316.

55. Lee V. The existential plight of cancer: meaning making as a concrete approach to the intangible search for meaning. Support Care Cancer 2008;16(7):779-785.

56. Lee V, Cohen SR, Edgar L, Laizner AM, Gagnon AJ. Clarifying "meaning" in the context of cancer research: a systematic literature review. Palliat Support Care 2004; 2(3):291-303.

57. Linley PA, Joseph S. Positive change following trauma and adversity: a review. J Trauma Stress 2004;17(1):11-21.

58. Breitbart W. Spirituality and meaning in cancer. Rev Francoph Psycho-Oncology 2005;4:237-240.

59. Henoch I, Danielson E. Existential concerns among patients with cancer and interventions to meet them: an integrative literature review. Psycho-Oncology 2009;18(3):225-236.

60. Taylor SE. Adjustment to threatening events - a theory of cognitive adaptation. Am Psychol 1983;38(11):1161-1173.

61. Taylor SE. Factors associated with meaning in life among people with recurrent cancer. Oncol Nurs Forum 1993;20:1399-1407.

62. Thompson SC, Sobolewshubin A, Galbraith ME, Schwankovsky L, Cruzen D. Maintaining perceptions of control-finding perceived control in low-control circumstances. J Pers Soc Psychol 1993;64(2):293-304.

63. Brady MJ, Peterman AH, Fitchett G, Mo M, Cella D. A case for including spirituality in quality of life measurement in oncology. Psycho-Oncology 1999;8(5):417-428.

64. Coward DD, Kahn DL. Transcending breast cancer: making meaning from diagnosis and treatment. J Holist Nurs 2005;23:264-283.

65. Lethborg C, Aranda S, Cox S, Kissane D. To what extent does meaning mediate adaptation to cancer? The relationship between physical suffering, meaning in life, and connection to others in adjustment to cancer. Palliat Support Care 2007;5(4):377-388.

66. Schroevers M, Kraaij V, Garnefski N. How do cancer patients manage unattainable personal goals and regulate their emotions? Br J Health Psychol 2008;13:551-562.

67. McCarthy Veach P, Bartels DM, LeRoy BS. Coming full circle: a reciprocal-engagement model of genetic counseling practice. J Genet Couns 2007;16:713-728.

68. Vos J, Menko FH, Jansen AM, Asperen CJV, Stiggelbout AM, Tibben A. A whisper-game perspective on the family communication of DNA-test results. Fam Cancer 2011;10(1): 87-96.

69. Holland J. Psychological care of patients: psycho-oncology's contribution. J Clin Oncol 2003;21(23S): 12.

70. Wakefield CE, Meiser B, Homewood J et al. Randomized trial of a decision aid for individuals considering genetic testing for hereditary nonpolyposis colorectal cancer risk. Cancer 2008;113(5):956-965.

71. Breitbart W, Rosenfeld B, Gibson C et al. Meaning-centered group psychotherapy for patients with advanced cancer: a pilot 
randomized controlled trial. Psycho-Oncology 2010;19(1):21-28.

72. Esplen MJ. Adjusting to potentially life altering genetic information: research findings on the role of existential group psychotherapy. Int Psychogeriatr 2003;15:3-4.

73. Lee V, Cohen SR, Edgar L, Laizner AM, Gagnon AJ. Meaning-making intervention during breast or colorectal cancer treatment improves self-esteem, optimism, and self-efficacy. Soc Sci Med 2006; 62(12):3133-3145.

74. Archer R. Dual Realities, The Search for Meaning. Psychodynamic Therapy with Physically Ill People. London: Karnac, 2006.
75. Janoff-Bulman R. In Shattered Assumptions: Towards a New Psychology of Trauma. The Free PressL: New York, 1992.

76. Vos J, Oosterwijk JC, Gomez-Garcia EB et al. Perceiving cancer-risks and heredity-likelihood in genetic-counseling: the analysis of the counselees' recollections and interpretations of BRCA1/2-test results. Clin Genet 2010. 